\title{
ASSESSMENT OF OCCUPATIONAL HEALTH PROBLEMS AND PHYSIOLOGICAL STRESS AMONG THE BRICK FIELD WORKERS OF WEST BENGAL, INDIA
}

\author{
BANIBRATA DAS \\ University of Calcutta, Kolkata, India \\ Department of Physiology, South Calcutta Girls' College
}

\begin{abstract}
Objectives: The brick field industry is one of the oldest industries in India, which employs a large number of workers of poor socioeconomic status. The main aim of the present investigation is i) to determine the prevalence of musculoskeletal disorders among brick field workers, ii) to determine the prevalence of respiratory disorders and physiological stress among brick field workers compared to control workers. Material and Methods: For this study, a total of 220 brick field workers and 130 control subjects were selected randomly. The control subjects were mainly involved in hand-intensive jobs. The Modified Nordic Questionnaire was applied to assess the discomfort felt among both groups of workers. Thermal stress was also assessed by measuring the WBGT index. The pulmonary functions were checked using the spirometry. Physiological assessment of the workload was carried out by recording the heart rate and blood pressure of the workers prior to work and just after work in the field. Results: Brick field workers suffered from pain especially in the lower back $(98 \%)$, hands $(93 \%)$, knees $(86 \%)$, wrists $(85 \%)$, shoulders $(76 \%)$ and neck $(65 \%)$. Among the brick-making activities, brick field workers felt discomfort during spading for mud collection (98\%), carrying bricks (95\%) and molding (87\%). The results showed a significantly lower $\mathrm{p}$ value $<0.001$ in $\mathrm{FVC}, \mathrm{FEV}_{1}, \mathrm{FEV}_{1} / \mathrm{FVC}$ ratio and PEFR in brick field workers compared to the control group. The post-activity heart rate of the brick field workers was 148.6 beats/min, whereas the systolic and diastolic blood pressure results were 152.8 and $78.5 \mathrm{~mm} / \mathrm{Hg}$, respectively. Conclusions: This study concludes that health of the brick field workers was highly affected due to working in unhealthy working conditions for a long period of time.
\end{abstract}

Key words:

Brick field workers, Physiological stress, Occupational health problems, Thermal stress, Lung function values, Hand-grip strength

\section{INTRODUCTION}

In India, occupational health problems are gaining momentum. Assessment of occupational health problems is one of the common fields of study of ergonomics. The brick field industry is one of the oldest industries in West Bengal, India. It involves a large number of workers of poor socioeconomic status. Brick field workers generally perform rigorous hand-intensive jobs for a sustained period of time and are forced to carry various amounts of load during their work, due to which they may suffer from musculoskeletal disorders (MSDs) and other occupational health problems. Musculoskeletal disorders (MSDs) can be caused by heavy physical work, static work postures, frequent bending and twisting, lifting, pushing and pulling, repetitive work, vibration and psychological and psychosocial stress [1]. In the brick field industry, the workers perform heavy manual tasks in

The project was financially supported by the University Grant Commission (UGC). UGC Reference No. F. PSW-147/11-12 (ERO) - An ergonomics study on occupational health problems of workers in unorganized sector of West Bengal and its probable management. Manager of the project: Banibrata Das, MSc, PhD. Received: October 1, 2013. Accepted: March 11, 2014.

Corresponding author: B. Das, Department of Physiology, South Calcutta Girls' College, University of Calcutta, Kolkata, India (e-mail: dr.banibrata@gmail.com). 
a repetitive manner for a prolonged period of time, which may lead to severe physical stress among them. Das [2] stated that the brick field workers found discomfort in different parts of the body due to working in an awkward posture for a long time. According to Burdorf and Sorock [3], manual material handling, awkward back postures and heavy physical work are work-related physical risk factors for low back pain.

Brick field workers perform several types of strenuous activity, such as: i) cutting the mud with a spade, ii) carrying the mud, iii) preparation of clay, iv) carrying the clay, v) molding, vi) stacking (loading and unloading the bricks), vii) carrying the bricks (green \& burn bricks), and viii) burning the bricks in kiln. During this process, brick field workers have to face a lot of problems. For instance, molders are directly exposed to dust which contains a mixture of inorganic compounds including free silica, iron oxide, etc. On the other hand, brick kiln workers (firemen) have to face very high temperature along with more proximal exposure to smoke and some toxic gases like sulfur dioxide, hydrogen sulfide, carbon dioxide and carbon monoxide, as well as particulate air pollutants while burning biomass fuels [4]. Adverse environmental and physical conditions affect the health status of brick field workers who perform also other types of activities, e.g. they have to walk on a hot surface (top of the furnace) while monitoring and regulating the fire. Physiological responses to such activities mainly involve the musculoskeletal and cardiovascular systems. Since the environment is unfriendly, it hinders excess heat elimination by the circulatory system, making the heart work harder to transport energy to the muscles for a successful completion of the job. An increase in age concurrently deteriorates the functional capacity [5].

\section{OBJECTIVES}

The main aim of the present investigation was i) to determine the prevalence of musculoskeletal disorders (MSDs) among brick field workers compared to control workers of the West Bengal, ii) to determine the prevalence of respiratory disorders among brick field workers exposed to dusts in the brick fields compared to the control workers, iii) to analyze thermal stress, iv) to assess physiological stress, and v) to identify unfavorable work conditions among the brick field workers.

\section{MATERIAL AND METHODS}

\section{Selection of subjects and working sites}

A cross-sectional study was conducted on 220 male brick field workers from 12 brick fields, working in a selected brick field unit of Bhadrakali in Hooghly district, which was situated at the side of the Hooghly River, 130 male control group subjects also selected randomly, who were engaged in office work involving minimum amount of hand-intensive job. The brick field unit was selected randomly from the surrounding area. The inclusion criteria of the selection of the subjects for both groups were: age 18-58 years, experience in different brick field activities or office activities for 1 year. The study was conducted from March 2012 to April 2013 at 20 brick fields. Our study participants (220 male brick field workers) were randomly selected from 752 brick field workers of 20 brick fields of Bhadrakali, Uttarpara and Kotrung area in Hooghly district, India.

The selected 220 male brick field workers generally perform different types of manual work in an awkward posture, which may cause the physical and biomechanical load. They carry huge weight of mud, raw brick and burn bricks on their heads, which affects their health. The 130 male control subjects are generally office workers responsible for the arrangement of files, distribution of documents in different sections of the office and serving tea, water and food to staff members on request. Among the 220 male brick field workers, 182 were smokers and 38 were non-smokers, whereas in case of 130 control subjects, 77 were smokers and 53 were non-smokers. 
Most smokers among male brick field workers smoked on average 11 beedi (small local type of cigar) per day, whereas smokers among the control subjects smoked on average 7 beedi/day.

\section{Measurement of physical parameters}

The height and weight of the brick field workers were measured by an anthropometer and a weighing machine, respectively. The body mass index (BMI) [6] of all the subjects was also computed. Before the survey, consent was taken from brick field owners as well as each individual subject. Written permission for the project was obtained from the Institutional Human Ethical Clearance Committee of the Indian Council of Medical Research Guidelines.

\section{Questionnaire study}

A detailed modified Nordic musculoskeletal disorder questionnaire [7] was developed and applied to the brick field workers as well as the controls. A questionnaire based on the modified Nordic musculoskeletal disorder questionnaire was completed by both groups. The questionnaire consisted of a number of objective questions, with multiple choice answers identifying the participant's personal viewpoints, pattern of work, duration of work, and discomfort levels in different parts of the body.

\section{Measurement of hand-grip strength}

A physical examination was performed by hand-grip dynamometer to measure the hand-grip strength of the brick field workers and compare the results with the control group. The brick field workers and the control subjects were asked to adopt an upright standing position without side bending, with arms at their side, not touching their body. The dynamometer should be gripped with full force [8]. The measurement was done twice in a day, prior to brick-making activities and just after their completion at $90^{\circ}$ elbow flexion and $180^{\circ}$ elbow flexion, as it has been observed that the highest and the lowest value of grip strength vary in accordance with the elbow position [9].

\section{Pulmonary Function Test (PFT)}

The examinations were performed with the use of a Spirometer (RMS HELIOS 401). Three successive recordings of forced vital capacity (FVC), forced expiratory volume in $1 \mathrm{~s}\left(\mathrm{FEV}_{1}\right)$ and forced expiratory ratio $\left(\mathrm{FEV}_{1} / \mathrm{FVC}\right.$ ratio) were performed in the standing position and the best of the 3 ratings was recorded.

Peak expiratory flow rate (PEFR) is the maximum flow rate generated during a forceful exhalation, starting from full lung inflation. It measures the airflow through the bronchi and thus the degree of obstruction in the airways. The measurement of the peak expiratory flow rate (PEFR) was done with a mini Wright's peak flow meter (Clement Clarke International, UK). Prior to recording the subjects' peak expiratory flow rate (PEFR), the use of the instrument was repeatedly demonstrated and explained to them. The peak expiratory flow rate (PEFR) test was performed in the standing position with the peak flow meter held horizontally. The subjects were asked to take as deep a breath as possible and then to blow out as hard and as quickly as possible. The best of the 3 ratings was recorded.

\section{Assessment of thermal stress}

The working environment of the brick field workers was assessed as follows. The wet bulb globe temperature (WBGT) index was calculated [10]. The mean globe temperature and wet and dry bulb temperatures were recorded. The formula for calculating the WBGT index for outdoor conditions is:

$$
\text { WBGT (outdoor) }=0.7(\mathrm{NWB})+0.2(\mathrm{GT})+0.1(\mathrm{DB})(1)
$$

where:

NWB - the natural wet bulb temperature,

DB - the dry bulb temperature,

GT - the globe temperature. 
Relative humidity was also estimated with a psychometric chart developed by Weksler Instrument (USA) [11].

\section{Assessment of physiological parameters}

Physiological stress assessment was carried out by recording the heart rate of the brick field workers prior to work and just after completion of work. The resting or prior-to-work heart rate was measured from the radial pulse for $1 \mathrm{~min}$ with the help of a stopwatch and the heart rate just after work was recorded from the carotid pulse with the 10 beats method [12]. The blood pressure of the brick field workers was measured with a sphygmomanometer and a stethoscope before and just after completion of work. Blood pressure measurements were made in 2 phases, one in a resting condition and the other just after completion of work among 2 groups of workers. Left arm blood pressure was taken with a sphygmomanometer and a stethoscope after the participant had been seated in a relaxed position for $5 \mathrm{~min}$ in a resting position. In case of the 2nd measurement, left arm blood pressure was taken with a sphygmomanometer and a stethoscope after the participant had been seated immediately after work. Systolic (SBP) and diastolic (DBP) blood pressures were recorded to the nearest $\mathrm{mm} \mathrm{Hg}$ as the appearance (phase I) and disappearance (phase V) of Korotkoff sounds, respectively.

Maximum heart rate (HRmax) was estimated from age following the equation of the American heart association [13]. Heart rate reserve (HRR) was calculated as the difference between the maximal and resting heart rate of the subjects. Net cardiac cost (NCC) was obtained as the difference between WHR (working heart rate) and resting heart rate, expressed as beats/min. Relative cardiac cost (RCC) was determined by expressing the NCC as the percentage of the heart rate reserve (HRR) of the subjects by using the following formula:

$$
\mathrm{RCC}=\mathrm{NCC} / \mathrm{HRR} \times 100
$$

\section{Data analysis}

Data were examined using the statistical package Primer of Biostatistics version 5.0 (Msi Version = 1.20.1827.0, Primer for Windows, Mc-Graw-Hill). Statistical analysis included calculation of the mean and standard deviation of the various physical parameters. In this study, normal samples were drawn from the normal population, so the Student's t-test was performed to find out whether there was any significant difference between the demographics of the brick field workers and the control group.

Comparisons of the means of different physiological parameters of the brick field workers and the control subjects were also made with the Student's t-test. A 2-tail Chi ${ }^{2}$ test of independence was applied to determine whether or not the test item had any significant association with discomfort. The computed $\mathrm{Chi}^{2}$ was next compared with the critical $\mathrm{Chi}^{2}$ values for the chosen level of significance ( $p$ value). One-way Anova test was also used to determine whether there was any significant difference between the hand-grip strength values of the brick field workers and the control subjects for the chosen level of significance $(\mathrm{p}<0.001)$

\section{RESULTS}

The mean values of age, height, weight, BMI and average years of working experience in both groups (brick field workers and control subjects) are shown in Table 1. The average duration of work among the brick field workers was $9.2 \mathrm{~h} /$ day $(\mathrm{SD}=1.2)$, and among the control subjects $-7.1 \mathrm{~h} /$ day $(\mathrm{SD}=1.3)$.

The analysis of the modified Nordic questionnaire presented in Table 2 showed that most brick field workers reported discomfort in different body parts. Most brick field workers felt discomfort mainly in the lower back (98\%), hands (93\%), knees (86\%), wrists $(83 \%)$ and shoulders $(76 \%)$, respectively. These results also showed that a large proportion of these problems lasted for more 
Table 1. Characteristics of the brick field workers and the control group

\begin{tabular}{lccrc}
\hline \multicolumn{1}{c}{ Variable } & $\begin{array}{c}\text { Brick field workers } \\
(\mathrm{N}=220)\end{array}$ & $\begin{array}{c}\text { Control group } \\
(\mathrm{N}=130)\end{array}$ & $\mathrm{t}$ & $\mathrm{p}$ \\
\hline Age (years) $(\mathrm{M} \pm \mathrm{SD})$ & $33.5 \pm 6.2$ & $34.2 \pm 6.7$ & 0.99 & 0.323 \\
Height $(\mathrm{cm})(\mathrm{M} \pm \mathrm{SD})$ & $169.2 \pm 4.1$ & $169.9 \pm 4.6$ & 1.47 & 0.141 \\
Weight $(\mathrm{kg})(\mathrm{M} \pm \mathrm{SD})$ & $55.2 \pm 6.2$ & $58.5 \pm 5.8$ & 4.92 & $<0.001$ \\
Body mass index $(\mathrm{M} \pm \mathrm{SD})$ & $18.8 \pm 1.8$ & $19.6 \pm 1.7$ & 4.10 & $<0.001$ \\
Seniority (years) $(\mathrm{M} \pm \mathrm{SD})$ & $14.2 \pm 4.8$ & $10.5 \pm 3.2$ & 7.82 & $<0.001$ \\
Average duration of work per day $(\mathrm{h})(\mathrm{M} \pm \mathrm{SD})$ & $9.2 \pm 1.2$ & $7.0 \pm 1.3$ & 16.00 & $<0.001$ \\
Working days in a week $(\mathrm{n})$ & 7 & 7 & - & - \\
\hline
\end{tabular}

$\mathrm{M}$ - mean; SD - standard deviation.

$\mathrm{t}$ - Student's t-test value.

Table 2. Feeling of discomfort in different parts of the body among the brick field workers and in the control group

\begin{tabular}{|c|c|c|c|c|}
\hline $\begin{array}{c}\text { Part } \\
\text { of the body }\end{array}$ & $\begin{array}{l}\text { Brick field workers } \\
\qquad(\mathrm{N}=220) \\
{[\mathrm{n}(\%)]}\end{array}$ & $\begin{array}{l}\text { Control group } \\
(\mathrm{N}=130) \\
{[\mathrm{n}(\%)]}\end{array}$ & $\mathrm{Chi}^{2}$ & $\mathrm{p}$ \\
\hline Neck & $142(65)$ & $3(2.0)$ & 127.00 & $<0.001$ \\
\hline Shoulders & $167(76)$ & $5(4.0)$ & 166.90 & $<0.001$ \\
\hline Elbows & $91(41)$ & $0(0.0)$ & 70.50 & $<0.001$ \\
\hline Wrists & $188(85)$ & $4(3.0)$ & 220.60 & $<0.001$ \\
\hline Hands & $204(93)$ & $8(6.0)$ & 252.80 & $<0.001$ \\
\hline Upper back & $33(15)$ & $0(0.0)$ & 19.80 & $<0.001$ \\
\hline Lower back & $216(98)$ & $28(22.0)$ & 195.90 & $<0.001$ \\
\hline Knees & $190(86)$ & $26(20.0)$ & 149.50 & $<0.001$ \\
\hline Ankles & $11(5)$ & $2(1.5)$ & 1.85 & 0.173 \\
\hline Feet & $32(15)$ & $1(1.0)$ & 16.58 & $<0.001$ \\
\hline
\end{tabular}

than 1 year, with many brick field workers experiencing prolonged discomfort (pain) for more than 5 years. However, the majority of those with a discomfort feeling were still able to continue their work. The control subjects suffered from pain especially in the lower back $(22 \%)$ and knees (20\%), and the pain in other parts of the body was negligible.

Table 3 shows the feeling of discomfort in the brick field workers engaged in various activities in the brick field.
Most of them reported discomfort during spading for mud collection (98\%), followed by carrying bricks (95\%), molding (87\%), loading and unloading bricks $(84 \%)$, setting bricks in the kiln (81\%), etc.

From Table 4 it was observed that there was a significant difference $(\mathrm{p}<0.05)$ in hand-grip strength measured at $90^{\circ}$ elbow flexion and $180^{\circ}$ elbow flexion just after stoppage of work between the brick field workers and the control subjects. In the resting condition, the 
Table 3. Feelings of discomfort (pain) during different activities in brick-making

\begin{tabular}{|c|c|c|}
\hline \multirow{2}{*}{$\begin{array}{l}\text { Activity } \\
\text { in the brick-making process }\end{array}$} & \multicolumn{2}{|c|}{$\begin{array}{l}\text { Brick field workers } \\
\qquad(\mathrm{N}=220)\end{array}$} \\
\hline & $\begin{array}{l}\text { participants affected } \\
\text { (n) }\end{array}$ & $\begin{array}{l}\text { feeling of discomfort } \\
(\%)\end{array}$ \\
\hline Spading for mud collection & 215 & 98 \\
\hline Loading mud & 166 & 75 \\
\hline Carrying mud & 155 & 70 \\
\hline Preparation of clay & 18 & 8 \\
\hline Carrying clay & 28 & 13 \\
\hline Molding & 192 & 87 \\
\hline Stacking & 116 & 53 \\
\hline Setting bricks in the kiln & 178 & 81 \\
\hline Loading and unloading bricks & 185 & 84 \\
\hline Carrying bricks & 210 & 95 \\
\hline
\end{tabular}

Table 4. Relationship between the hand-grip strength in the brick field workers and in the control group

\begin{tabular}{clcrrr}
\hline \multicolumn{1}{c}{ Hand-grip strength } & \multicolumn{1}{c}{ Condition } & $\begin{array}{c}\text { Brick field workers } \\
(\mathrm{N}=220) \\
(\mathrm{M} \pm \mathrm{SD})\end{array}$ & $\begin{array}{c}\text { Control group } \\
(\mathrm{N}=130) \\
(\mathrm{M} \pm \mathrm{SD})\end{array}$ & $\mathrm{F}$ & $\mathrm{p}$ \\
\hline At $90^{\circ}$ elbow flexion $(\mathrm{kg})$ & resting condition & $41.20 \pm 4.28$ & $40.98 \pm 3.32$ & 0.25 & 0.615 \\
& just after stoppage of work & $35.88 \pm 2.28$ & $37.25 \pm 2.36$ & 28.74 & $<0.001$ \\
At $180^{\circ}$ elbow flexion $(\mathrm{kg})$ & resting condition & $41.20 \pm 4.28$ & $40.98 \pm 3.32$ & 0.25 & 0.615 \\
& just after stoppage of work & $34.92 \pm 2.23$ & $36.88 \pm 2.68$ & 54.20 & $<0.001$ \\
\hline
\end{tabular}

F - F distribution under null hypothesis. Other abbreviations as in Table 1.

brick field workers had higher hand-grip strength than the control subjects, but soon after completion of work there was a marked decrease in the hand-grip strength among the brick field workers compared to the control subjects.

Table 5 presents the thermal stress associated with different brick-making activities. It was noted that the brick field workers suffered from heavy thermal stress during the last stages of brick-making. Setting the bricks in kiln and loading the burn bricks from the kiln are the main activities that are carried out at temperatures exceeding $32^{\circ} \mathrm{C}$ with an $80-90 \%$ relative humidity.
Table 6 shows the comparison of the lung function parameters between brick field workers and the control subjects. There was a significant difference in spirometry findings (FVC, $\mathrm{FEV}_{1}, \mathrm{FEV}_{1} / \mathrm{FVC}$ ratio, PEFR) between brick field workers and the control subjects. It can be said that the changes in pulmonary variables in brick field workers in comparison to the control subjects were due to the constant exposure to unhealthy working conditions, which deteriorated the pulmonary health condition of the brick field workers. Table 7 shows the pulmonary function test among smokers and non-smokers, in which the significant change was observed in case of FVC (l), $\mathrm{FEV}_{1}(\mathrm{l})$ and PEFR (1/min) 
Table 5. Average temperatures during different activities (outdoor WBGT index of the workshops) in the brick-making process

\begin{tabular}{|c|c|c|c|c|}
\hline Activity during brick-making & Thermometer & $\begin{array}{l}\text { Average temperature } \\
\qquad\left({ }^{\circ} \mathrm{C}\right)\end{array}$ & $\begin{array}{l}\text { WBGT index } \\
\left({ }^{\circ} \mathrm{C}\right)\end{array}$ & $\begin{array}{c}\text { Relative humidity } \\
(\%)\end{array}$ \\
\hline \multirow[t]{3}{*}{ Spading for mud collection } & globe & 36.2 & 25.6 & 78 \\
\hline & wet bulb & 22.4 & & \\
\hline & dry bulb & 26.1 & & \\
\hline \multirow[t]{3}{*}{ Loading mud } & globe & 36.2 & 25.6 & 78 \\
\hline & wet bulb & 22.4 & & \\
\hline & dry bulb & 26.1 & & \\
\hline \multirow[t]{3}{*}{ Carrying mud } & globe & 36.2 & 25.6 & 78 \\
\hline & wet bulb & 22.4 & & \\
\hline & dry bulb & 26.1 & & \\
\hline \multirow[t]{3}{*}{ Preparation of clay } & globe & 37.4 & 26.3 & 82 \\
\hline & wet bulb & 23.1 & & \\
\hline & dry bulb & 26.3 & & \\
\hline \multirow[t]{3}{*}{ Carrying clay } & globe & 37.4 & 26.3 & 82 \\
\hline & wet bulb & 23.1 & & \\
\hline & dry bulb & 26.3 & & \\
\hline \multirow[t]{3}{*}{ Molding } & globe & 37.4 & 26.3 & 82 \\
\hline & wet bulb & 23.1 & & \\
\hline & dry bulb & 26.3 & & \\
\hline \multirow[t]{3}{*}{ Stacking bricks } & globe & 35.3 & 26.7 & 84 \\
\hline & wet bulb & 24.2 & & \\
\hline & dry bulb & 26.8 & & \\
\hline \multirow[t]{3}{*}{ Setting bricks in the kiln } & globe & 37.5 & 33.2 & 82 \\
\hline & wet bulb & 31.7 & & \\
\hline & dry bulb & 34.8 & & \\
\hline \multirow[t]{3}{*}{ Loading and unloading bricks } & globe & 35.3 & 32.0 & 89 \\
\hline & wet bulb & 30.9 & & \\
\hline & dry bulb & 32.7 & & \\
\hline \multirow[t]{3}{*}{ Carrying bricks } & globe & 35.3 & 32.0 & 89 \\
\hline & wet bulb & 30.9 & & \\
\hline & dry bulb & 32.7 & & \\
\hline
\end{tabular}

WBGT - wet bulb globe temperature. 
Table 6. Lung function test parameters in the brick field workers and in the control group

\begin{tabular}{lcccc}
\hline Parameter & $\begin{array}{c}\text { Brick field workers } \\
(\mathrm{N}=220) \\
(\mathrm{M} \pm \mathrm{SD})\end{array}$ & $\begin{array}{c}\text { Control group } \\
(\mathrm{N}=130) \\
(\mathrm{M} \pm \mathrm{SD})\end{array}$ & $\mathrm{t}$ & $\mathrm{p}$ \\
\hline FVC $(\mathrm{l})$ & $3.38 \pm 0.12$ & $4.16 \pm 0.15$ & 53.40 & $<0.001$ \\
$\mathrm{FEV}_{1}(\mathrm{l})$ & $2.58 \pm 0.15$ & $3.58 \pm 0.18$ & 55.90 & $<0.001$ \\
$\mathrm{FEV}_{1} / \mathrm{FVC}(\%)$ & $76.33 \pm 3.24$ & $86.05 \pm 1.93$ & 31.10 & $<0.001$ \\
PEFR $(\mathrm{l} / \mathrm{min})$ & $412.20 \pm 48.72$ & $472.50 \pm 41.74$ & 11.78 & $<0.001$ \\
\hline
\end{tabular}

$\mathrm{FVC}$ - forced vital capacity; $\mathrm{FEV}_{1}$ - forced expiratory volume in $1 \mathrm{~s} ; \mathrm{FEV}_{1} / \mathrm{FVC}$ - forced expiratory ratio; PEFR - peak expiratory flow rate. Other abbreviations as in Table 1.

Table 7. Pulmonary function test results of smokers and non-smokers (brick field workers and the control group)

\begin{tabular}{|c|c|c|c|c|c|c|c|c|}
\hline \multirow{2}{*}{ Parameter } & \multicolumn{2}{|c|}{$\begin{array}{l}\text { Brick field workers } \\
\qquad(\mathrm{M} \pm \mathrm{SD})\end{array}$} & \multirow{2}{*}{$\mathrm{t}$} & \multirow{2}{*}{$\mathrm{p}$} & \multicolumn{2}{|c|}{$\begin{array}{l}\text { Control group } \\
(\mathrm{M} \pm \mathrm{SD})\end{array}$} & & \multirow{2}{*}{$\mathrm{p}$} \\
\hline & $\begin{array}{l}\text { smokers } \\
(\mathrm{N}=182)\end{array}$ & $\begin{array}{l}\text { non-smokers } \\
\quad(\mathrm{N}=38)\end{array}$ & & & $\begin{array}{l}\text { smokers } \\
(\mathrm{N}=77)\end{array}$ & $\begin{array}{l}\text { non-smokers } \\
\quad(\mathrm{N}=53)\end{array}$ & & \\
\hline FVC (l) & $3.18 \pm 0.14$ & $3.77 \pm 0.13$ & 23.90 & $<0.001$ & $4.12 \pm 0.14$ & $4.22 \pm 0.16$ & 3.770 & $<0.001$ \\
\hline $\mathrm{FEV}_{1}(\mathrm{l})$ & $2.47 \pm 0.13$ & $2.88 \pm 0.16$ & 16.90 & $<0.001$ & $3.54 \pm 0.16$ & $3.64 \pm 0.19$ & 3.240 & 0.002 \\
\hline $\mathrm{FEV}_{1} / \mathrm{FVC}(\%)$ & $77.67 \pm 3.22$ & $76.39 \pm 3.28$ & 2.22 & 0.027 & $85.92 \pm 1.88$ & $86.25 \pm 1.98$ & 0.962 & 0.338 \\
\hline PEFR (1/min) & $408.20 \pm 46.21$ & $426.80 \pm 49.28$ & 2.23 & 0.027 & $459.80 \pm 40.24$ & $490.50 \pm 43.21$ & 4.140 & $<0.001$ \\
\hline
\end{tabular}

Abbreviations as in Table 1 and 6.

among the smokers and non-smokers in the examined groups.

The heart rates of the brick field workers are given in Table 8. It was found that the heart rate rose to more than 100 beats per min during almost all the activities (except preparation of clay). It was also observed that the heart rate was highest during spading (148 beats/min) for mud collection, showing that it is the most strenuous of all the tasks. Table 9 presents physiological stress of the brick field workers and the control subjects. The resting heart rate and blood pressure (systolic and diastolic) of both groups did not show any significant change; whereas, just after work, the heart rate and blood pressure (systolic and diastolic) of both the brick field workers and the control subjects showed a significant change.

Table 8. Comparative physiological stress (heart rate) in the brick field workers and in the control group

\begin{tabular}{|c|c|c|c|c|}
\hline \multirow{2}{*}{ Activity in the brick field } & \multicolumn{2}{|c|}{$\begin{array}{l}\text { Heart rate (beats/min) } \\
\qquad(\mathrm{M} \pm \mathrm{SD})\end{array}$} & \multirow{2}{*}{$\mathrm{t}$} & \multirow{2}{*}{$\mathrm{p}$} \\
\hline & $\begin{array}{l}\text { brick field workers } \\
\quad(\mathrm{N}=220)\end{array}$ & $\begin{array}{c}\text { control group } \\
(\mathrm{N}=130)\end{array}$ & & \\
\hline Resting & $88.2 \pm 4.4$ & $87.5 \pm 3.8$ & 1.51 & 0.132 \\
\hline Spading for mud collection & $148.6 \pm 5.3$ & $96.8 \pm 4.9$ (just after work) & 90.80 & $<0.001$ \\
\hline
\end{tabular}


Table 8. Comparative physiological stress (heart rate) in the brick field workers and in the control group - cont.

\begin{tabular}{|c|c|c|c|c|}
\hline \multirow{2}{*}{ Activity in the brick field } & \multicolumn{2}{|c|}{$\begin{array}{l}\text { Heart rate (beats/min) } \\
\qquad(\mathrm{M} \pm \mathrm{SD})\end{array}$} & \multirow{2}{*}{$\mathrm{t}$} & \multirow{2}{*}{$\mathrm{p}$} \\
\hline & $\begin{array}{l}\text { brick field workers } \\
\qquad(\mathrm{N}=220)\end{array}$ & $\begin{array}{l}\text { control group } \\
(\mathrm{N}=130)\end{array}$ & & \\
\hline Loading mud & $128.1 \pm 3.2$ & & 72.20 & $<0.001$ \\
\hline Carrying mud & $137.1 \pm 4.8$ & & 75.30 & $<0.001$ \\
\hline Preparation of clay & $94.2 \pm 3.7$ & & 5.61 & $<0.001$ \\
\hline Carrying clay & $106.2 \pm 5.1$ & & 16.90 & $<0.001$ \\
\hline Molding & $100.3 \pm 4.2$ & & 7.07 & $<0.001$ \\
\hline Stacking bricks & $102.5 \pm 5.5$ & & 9.74 & $<0.001$ \\
\hline Setting bricks in the kiln & $108.2 \pm 6.2$ & & 17.90 & $<0.001$ \\
\hline Loading and unloading bricks & $110.5 \pm 5.8$ & & 22.60 & $<0.001$ \\
\hline Carrying bricks & $132.8 \pm 6.3$ & & 55.90 & $<0.001$ \\
\hline
\end{tabular}

Abbreviations as in Table 1.

Table 9. Physiological and physical workload in the brick field workers and in the control group

\begin{tabular}{lcrrr}
\hline \multicolumn{1}{c}{ Physiological parameter } & $\begin{array}{c}\text { Brick field workers } \\
(\mathrm{N}=220) \\
(\mathrm{M} \pm \mathrm{SD})\end{array}$ & $\begin{array}{c}\text { Control group } \\
(\mathrm{N}=130) \\
(\mathrm{M} \pm \mathrm{SD})\end{array}$ & $\mathrm{t}$ & $\mathrm{p}$ \\
\hline Heart rate (beats/min) & & & & \\
$\quad$ resting & $88.2 \pm 4.4$ & $88.5 \pm 3.8$ & 0.648 & 0.518 \\
$\quad$ just after work & $148.6 \pm 5.3$ & $96.8 \pm 4.9$ & 90.820 & $<0.001$ \\
Blood pressure systolic (mm Hg) & & & & \\
resting & $112.2 \pm 5.6$ & $116.7 \pm 5.3$ & 7.400 & $<0.001$ \\
just after work & $152.8 \pm 3.9$ & $120.8 \pm 4.1$ & 72.760 & $<0.001$ \\
Diastolic (mm Hg) & & & & \\
resting & $78.5 \pm 4.7$ & $80.8 \pm 4.8$ & 4.380 & $<0.001$ \\
just after work & $88.2 \pm 5.3$ & $82.0 \pm 5.5$ & 10.420 & $<0.001$ \\
HRmax & $186.5 \pm 5.6$ & $185.8 \pm 5.1$ & 1.160 & 0.244 \\
HRR & $98.3 \pm 4.9$ & $97.3 \pm 4.3$ & 1.920 & 0.055 \\
NCC & $60.4 \pm 4.2$ & $8.3 \pm 5.1$ & 103.400 & $<0.001$ \\
RCC & $61.4 \pm 4.6$ & $8.53 \pm 4.0$ & 108.930 & $<0.001$ \\
\hline
\end{tabular}

HRmax - maximum heart rate; HRR - heart rate reserve; NCC - net cardiac cost; RCC - relative cardiac cost.

Other abbreviations as in Table 1. 


\section{DISCUSSION}

The prevalence of occupational health hazards has been reported as high among people of India [14]. The results of the study also revealed that the brick field workers (an experimental group) were engaged in rigorous handintensive jobs for many years, whereas the control group was not involved in such type of work.

It was also found that brick field workers suffered from discomfort in different parts of the body, especially in the lower back, knees and upper extremities. The study mainly shows that the physical as well as biomechanical load of the brick field workers is high in comparison to the control group of workers due to carrying heavy loads in an awkward posture for prolonged period of time.

As demonstrated by Das [2], the postures adopted by the brick field workers during work were characterized by high risk and needed correction immediately. Das [2] and Mukhopadhyay [15] stated that musculoskeletal disorders were observed among the brick field workers due to carrying heavy loads (manual material handling) for a long period of time. This study also revealed that brick field workers felt discomfort in their knees due to kneeling for a prolonged period of time during molding, during loading and unloading the mud and bricks, and while setting the green bricks in the kiln. Jensen et al. support this result [16]. According to them, the prevalence of knee disorders in some occupations was possibly related to kneeling working postures.

This study also indicates clearly that brick carriers mainly carry the bricks on their head. They take 8-10 bricks at a time with approximate total weight of $25-30 \mathrm{~kg}$ ( 1 brick $=4.5-5 \mathrm{~kg}$ ), which ultimately leads to head, neck and shoulder pain among them. This result was supported by Sahu et al. [17]. According to them, head is the most affected part among the brick carriers. They also added that female brick carriers carry $50 \mathrm{~kg}$ and above of load on their head, which exceeds the recommended weight limit (RWL) for Indian adult women. Manual material handling is the cheapest solution in developing countries [18]. Therefore, most of the brick carriers mainly perform such handling. To avoid musculoskeletal disorders, this study suggests decreasing the physical load of the workers and carrying the bricks and mud in the trolley. The results of the study also showed that the brick field workers perform mainly 2 types of hard jobs: brick molding (manufacturing) and carrying. Brick manufacturing workers and brick carriers are engaged in rigorous handintensive jobs in a repetitive manner. According to them, spading for the collection of mud for brick-making is an extremely demanding process in which the subjects felt discomfort. This clearly establishes the fact that the feeling of discomfort associated with spading can be attributed to a number of factors. Thus, highly forceful work may be regarded as a causative factor for the development of musculoskeletal disorders in the upper limbs among brick field workers.

Hand-grip strength of both groups was measured at $90^{\circ}$ and $180^{\circ}$ elbow flexion during rest and just after work. There was a significant difference in the hand-grip strength just after work between the brick field workers and the control group. If brick field workers are constantly engaged in hand-intensive jobs, they may be affected by discomfort (pain) in the upper extremities and significant changes in the hand-grip strength [19]. This result also corroborates with the work of Das et al. [20] and Alperovitch-Najenson et al. [21] who suggest that workers, constantly engaged in hand-intensive jobs, are likely to suffer from upper limbs MSDs. Our results revealed that the decreased hand-grip strength may be related to increased loading at the proximal end, that is, muscles at the cervical spine and shoulder joints may have to exert greater forces in order to control the arm movements.

Occupational risk factors are one of the major causes of respiratory illnesses and symptoms. This study shows that the $\mathrm{FVC}, \mathrm{FEV}_{1}, \mathrm{FEV}_{1} / \mathrm{FVC}$ ratio and PEFR values are much lower among the brick field workers, due to 
inhalation of dust particles in the brick fields, compared to the control group. According to Das et al. [22] and Shaikh et al. [4], brick field workers often face several health hazards while performing occupational activities and their PEFR values are much lower than in the control group of workers.

Most brick field workers reported physiological stress during different activities in the process of brick-making. The heart rate is the best indicator of the physiological parameters. The fact that the heart rate of the brick carriers measured just after completion of work was very high may be due to constant movement of the body. Moreover, when a brick carrier bends forward to collect the bricks, the muscles of the abdomen contract and the muscles of the back are stretched. This contracting and stretching of the muscles requires energy. Thus, the heart rates are increased.

According to Mukhopadhyay [15], the relative duration of working in the sun was critical in his subjects and this was substantiated by the elevated physiological parameters well above the normal resting value. Guyton [23] supported the results of this study stating that stretching the muscles causes muscle vasoconstriction, which results in restricted blood flow and increased systolic blood pressure.

This study revealed that there was a significant change in the diastolic blood pressure due to the erect and rigid posture among the brick field workers. Guyton [23] also found that diastolic blood pressure increased during certain activities when the posture was erect and rigid. Moreover, blood pooling in any part of the body causes muscle vasodilatation and an increase in the diastolic blood pressure.

\section{Limitation of study}

This study had some limitations. A retrospective study is needed to identify the long-term biomechanical and physiological stress among the brick field workers. There are also other factors that have not been investigated, such as repetition of the work in a sequential posture, an analysis of accidents and psychological factors of the brick field workers and an EMG study of the brick field workers in whom muscle fatigue during work can be assessed.

\section{Recommendation}

1. The work schedule should be changed by increasing the number of short rest breaks to avoid excessive physical stress.

2. Different types of stretching exercises should be practiced during the breaks.

3. Job rotation among the brick field workers should also be considered.

4. Masks should be used especially during molding to avoid the inhalation of dust particles.

5. The brick field workers should frequently change their posture to avoid discomfort.

6. The brick carriers should carry the bricks in the trolley, and not in the upper extremities.

7. Smokers of both groups should reduce their smoking habits, otherwise the physiological parameters (blood pressure, hypertension, condition of lungs, heart rate) will seriously affect their health condition.

\section{CONCLUSIONS}

The conclusions reached from the investigation are as follows:

1. This study mainly shows that brick field workers are suffering from musculoskeletal disorders (MSDs) especially in the upper extremities of the body, lower back and knees due to working in a kneeling posture and an awkward (stooping, squatting and twisting) posture for a long period of time.

2. This study indicates that brick field workers have lower hand-grip strength due to performing more strenuous hand-intensive jobs than the control subjects. 
3. The $\mathrm{FEV}_{1}, \mathrm{FEV}_{1} / \mathrm{FVC}$ ratio and PEFR values of the brick field workers are much lower than those in the control subjects due to inhalation of dust particles in the brick fields.

4. Brick field workers suffer from thermal stress during the last part of brick manufacturing, which affects their health.

5. Brick field workers suffer from severe physiological stress due to hazardous working conditions and work behavior. Increased heart rates and blood pressure also affect their health and the overall work performance.

\section{Future research}

The future research needs have been identified as follows:

1. The nutritional status of the brick field workers should be obtained by a diet survey.

2. Known co-morbidities that contribute to musculoskeletal disorders (such as diabetes, hypertension, thyroid disease, pregnancy, etc.) should be studied.

\section{ACKNOWLEDGEMENTS}

The authors would like to thank all the brick field workers and brick field owners for their immense cooperation during this study.

\section{REFERENCES}

1. Andersson GBJ. Epidemiological aspects on low back pain in industry. Spine. 1981;6:53-60, http://dx.doi. org/10.1097/00007632-198101000-00013.

2. Das B. Prevalence of work related musculoskeletal disorder among the brick field workers of West Bengal, India. Arch Environ Occup Health. 2014;69(4):231-40, http://dx.doi.org/ 10.1080/19338244.2013.771249.

3. Burdorf A, Sorock G. Positive and negative evidence of risk factors for back disorders. Scand J Work Environ Health. 1997;23(4):243-56, http://dx.doi.org/10.5271/ sjweh.217.
4. Shaikh S, Nafees AA, Khetpal V, Jamali AA, Arain AM, Yousuf A. Respiratory symptoms and illnesses among brick kiln workers: A cross sectional study from rural districts of Pakistan. BMC Public Health. 2012;12:999-1004, http:// dx.doi.org/10.1186/1471-2458-12-999.

5. Garg A. Ergonomics and the older worker: An overview. Exp Aging Res. 1991;17(3):143-55.

6. Cole TJ, Bellizzi MC, Flegal KM, Dietz WH. Establishing a standard definition for child overweight and obesity worldwide: International survey. BMJ. 2000;6:1240-3, http:// dx.doi.org/10.1136/bmj.320.7244.1240.

7. Dickinson CE, Campion K, Foster AF, Newman SJ, O'Rourke AMT, Thomas PG. Questionnaire development: An examination of the Nordic Musculoskeletal questionnaire. Appl Ergon. 1992;23(3):197-201, http://dx.doi. org/10.1016/0003-6870(92)90225-K.

8. MacDermid JC, Kramer JF, Woodbury MG, McFarlane RM, Roth JH. Interrater reliability of pinch and grip strength measurement in patients with cumulative trauma disorders. J Hand Ther. 1994;7:10-4, http://dx.doi. org/10.1016/S0894-1130(12)80035-4.

9. Su CY, Lin JH, Chien TH, Cheng KF, Sung YT. Grip strength: Relation to shoulder position in normal subjects. Arch Phys Ment Rehab. 1994;75:812-5.

10. Yaglou CP, Minard D. Control of heat casualties at military training centers. AMA Arch Ind Health. 1957;16:302-16.

11. Tayyari F, Smith JL. Occupational ergonomics. London: Chapman \& Hall; 1997.

12. Astrand P, Rodhall K. Textbook of work physiology. 3rd ed. New York: McGraw-Hill; 1986. p. 501-2.

13. American Heart Association, Committee of Exercise. Exercise testing and training of apparently healthy individual: A handbook of physician. New York: American Heart Association; 1972.

14. Das B, Gangopadhyay S. Prevalence of musculoskeletal disorders and physiological stress among adult, male potato cultivators of West Bengal, India. Asia Pac J Public Health. 2012; Jan 13, http://dx.doi.org/10.1177/1010539511421808. 
15. Mukhopadhyay P. Risk factors in manual brick manufacturing in India. HFESA J Ergon Aust. 2008;22(1):16-25.

16. Jensen LK, Mikkelsen S, Loft IP, Eenberg W. Workrelated knee disorders in floor layers and carpenters. J Occup Environ Med. 2000;42(8):835-42, http://dx.doi. org/10.1097/00043764-200008000-00015.

17. Sahu S, Sett M, Gangopadhyay S. An ergonomic study on teenage girls working in the manual brick manufacturing units in the unorganized sectors in West Bengal, India. J Hum Ergol. 2010;39(1):23-33.

18. Maiti R. Work load assessment in building construction related activities in India. Appl Ergon. 2008;39:754-65, http:// dx.doi.org/10.1016/j.apergo.2007.11.010.

19. Gangopadhyay S, Ghosh T, Das T, Ghoshal G, Das B. Prevalence of upper limb musculoskeletal disorders among brass metal workers in West Bengal, India. J Ind Health. 2007;45(2):365-70, http://dx.doi.org/10.2486/indhealth.45.365.

20. Das B, Ghosh T, Gangopadhyay S. Assessment of ergonomical and occupational health related problem among the female prawn seed collectors of sunderban, West Bengal, India. Int J Occup Saf Ergon. 2012;18:531-40.

21. Alperovitch-Najenson D, Carmeli E, Coleman R, Ring H. Handgrip strength as a diagnostic tool in work-related upper extremity musculoskeletal disorders in women. Sci World J. 2004;4:111-7, http://dx.doi.org/10.1100/tsw.2004.12.

22. Das B, Ghosh T, Gangopadhyay S. Peak expiratory flow rate among child labourers in West Bengal, India. Indian Pediatr. 2011;48:487-8.

23. Guyton AC. Text book of medical physiology. 8th ed. Bangalore: Prism Books; 1991.

This work is available in Open Access model and licensed under a Creative Commons Attribution-NonCommercial 3.0 Poland License - http://creativecommons.org/ licenses/by-nc/3.0/pl/deed.en. 